\title{
Review of hatchery transmission of bacteria with focus on Salmonella, chick pathogens and antimicrobial resistance
}

\author{
Andrew Wales', Robert Davies ${ }^{2}$ \\ ${ }^{1}$ Department of Pathology and Infectious Diseases, School of Veterinary Medicine, Faculty of Health and \\ Medical Sciences, Vet School Main Building, Daphne Jackson Road, University of Surrey, Guildford GU2 \\ 7AL, UK. \\ 2Department of Bacteriology and Food Safety and ${ }^{2}$ Department of Epidemiological Sciences, Animal and \\ Plant Health Agency (APHA - Weybridge), Woodham Lane, New Haw, Addlestone, KT15 3NB, UK.
}

This is an Accepted Manuscript of an article published by Taylor \& Francis in World's Poultry Science Journal on 26 Oct 2020, available online:

https://www.tandfonline.com/10.1080/00439339.2020.1789533

\section{Summary}

Commercial hatcheries for poultry potentially provide a sanitary barrier between breeder flocks and their progeny. This is important, particularly within the pyramidal breeding structures serving integrated poultry production systems. However, the operation of hatcheries and their focal position connected with multiple flocks, both on the input and output sides, means that they are vulnerable to becoming disseminators of infectious agents. Of particular concern for hatcheries is the pseudo-vertical transmission of bacteria that are initially deposited at the surface of forming or freshly-laid eggs. These bacteria (of which Salmonella enterica is a prime example) can subsequently be present in the chick, as well as spreading within the hatchery environment to colonise other hatching birds. Furthermore, if such infectious organisms become persistent in parts of the hatchery environment, this allows their repeated transfer to hatching individuals or even (via personnel and fomites) to transfer back into breeding flocks supplying the hatchery. The use of antimicrobial drugs in hatcheries adds the further hazard of seeding progeny with antimicrobial-resistant organisms.

The mechanisms of hatchery, egg and subsequent chick contamination have been understood, and strategies to counteract the spread and persistence of infectious agents are wellestablished. However, many studies examining bacterial pathogens and antimicrobial-resistant organisms in poultry production implicate hatcheries, either as a link in a chain or as a source of such agents. The review outlines the challenges posed by hatchery operation to control of bacterial transmission, it examines the contemporary and historical evidence for such phenomena, and it briefly discusses strategies to counteract the issue. 


\section{Introduction}

Modern commercial poultry production adopts a pyramidal breeding structure, with male and female traits maintained in separate lines in the small-volume upper tiers, plus physical separation between flocks of different generational layers within the pyramid (Pollock 1999, Dame-Korevaar et al. 2019). Hatcheries are positioned between each layer, producing progeny for the next layer down. By contrast to live-bearing farmed mammals, this physical segregation of generations provides a potential barrier for the transmission of harmful microbiological agents.

However, despite the clear spatial separation of breeders and their progeny, certain features of egg and chick biology and of hatchery operation create many opportunities for the transmission of infectious agents, particularly those of a bacterial nature, down the breeding pyramid. The present review outlines the mechanisms by which this transmission can happen, the evidence for its occurrence, and methods of preventing it. The focus is upon zoonotic and antimicrobial resistant bacteria, principally comprising Salmonella, avian-pathogenic E. coli and other members of the Enterobacteriaceae.

\section{Hatchery operation, vulnerabilities and infection issues}

Commercial hatcheries typically receive eggs from breeding flocks, apply a sanitising procedure to them and then incubate them in 'setter' incubators. Shortly before hatch, typically at 18 days of incubation for chickens, the eggs are transferred to 'hatcher' incubators, where they are held in hatching baskets. They can be candled at this transfer stage to detect and remove infertile eggs. Once hatching is complete, progeny are removed from hatchers, sexed where required, vaccinated and either dispatched to rearing accommodation in crates or, in the case of males of laying hen lines, subjected to humane destruction.

Hatcheries are vulnerable to infectious agents that may arrive on or within eggs, on staff, on fomites such as trolleys and trays, or as airborne contaminants. Furthermore, some microbes that survive exposure to sanitisation treatments, or evade treatment by virtue of location, can then survive incubation without destroying egg viability. These processes can lead to infection of chicks during incubation or at hatching. Infectious agents with such potential include bacteria (such as members of the Enterobacteriaceae), fungi such as Aspergillus fumigatus, and the environmentally-stable Newcastle Disease virus (McMullin 2009).

In some cases eggs are already internally-colonised on arrival, giving rise to vertical transmission of infection to progeny. Mycoplasmas are an important pathogen group showing true vertical transmission (Bradbury 2006, McMullin 2009, Morrow and Browning 2018). By contrast, many Salmonella serovars and other bacteria can exhibit pseudo-vertical transmission, where microbes are initially present on the outside surface of the egg but are drawn in through shell pores in the cooling, moist, freshly-laid egg and subsequently penetrate or establish in the shell membranes (Berrang et al. 1999, Cox et al. 2000b).

A further challenge to hatchery control of infection is the risk of the horizontal spread of infectious agents between eggs and between chicks, where the hatchery may function as a reservoir and multiplier of microbes. The typical strategy to counteract this involves surfacesanitising eggs effectively on arrival and attempting to avoid their subsequent recontamination within the premises. The latter issue is addressed by controlling the movement 
and contamination of fomites (including vehicles and egg handling/transport equipment) by batch management, by controlling workflow, airflow and staff movements, and by effective cleaning and disinfection (C\&D) of the hatchery and its equipment (Anon. 2016, Bennett 2017). The risk also exists of 'upstream' transmission of infectious agents from hatchery to breeder flocks via fomites such as egg trolleys and trays, and also via vehicles and drivers (MuellerDoblies et al. 2013).

Effective sanitisation of eggshells will greatly reduce the surface flora of mixed bacterial and fungal species. However, bacteria that have already penetrated the shell pores will largely be shielded from such antimicrobial treatments. Although the egg is equipped with antimicrobial defences in addition to the physical barrier of the shell and its membranes, Gram-negative bacteria appear to enjoy a survival advantage inside the egg, perhaps owing to an inherently lower susceptibility to lysozyme and/or other antibacterial components of egg albumen (Silvetti et al. 2017), and they may survive during incubation within the shell membranes (Berrang et al. 1999, De Reu et al. 2008). Certain motile bacteria can also traverse the hostile environment of the albumen to infect the developing embryo (Berrang et al. 1999). Deep penetration may result in death of the embryo, plus or minus putrefaction of the egg, but some important bacteria (notably Salmonella serovar Enteritidis and experimentally some strains of Typhimurium) can infect the developing embryo without loss of viability (Cason et al. 1994, Yassin et al. 2008).

The process of hatching represents a time of extreme vulnerability for infection and crossinfection of chicks. Some chicks may hatch having already been colonised by an egg-invasive pathogen such as Salmonella, whilst others may be exposed to pathogenic or antimicrobialresistant Gram-negative organisms via respiratory or alimentary routes as they break through the shell membranes and shell. Normally, chicks hatch with an uncolonised gut and are highly susceptible to colonisation by pathogens or antimicrobial-resistant bacteria in the hatcher environment (Cox et al. 1996, Byrd et al. 1998, Baron et al. 2014), with one experimental study showing approximately $50 \%$ of day-old chicks being colonised following an oral dose of just $10^{1} \mathrm{cfu}$ Salmonella Typhimurium (Milner and Shaffer 1952).

For chicks that hatch in isolation from adult hens, early colonisation is dominated by Grampositive bacteria, members of the phylum Firmicutes (Videnska et al. 2014). By contrast, chicks that are exposed to adult hens (or their gut microbiota) immediately after hatching develop a balance between Gram-positive and Gram-negative bacteria from an early stage, have less intense colonisation by cells of potentially pathogenic genera such as Clostridium and Escherichia, and show higher resistance to colonisation by Salmonella Enteritidis (Varmuzova et al. 2016, Kubasova et al. 2019). The advantages of colonisation by commensal microbiota have led to the use in some cases of competitive exclusion microbiological treatments. However benefits, in terms of resistance to pathogens in the hatcher environment, appear to be dependent in part on very early administration of such products (Varmuzova et al. 2016).

The hatching process generates substantial amounts of airborne dust, fluff and associated micro-organisms within and around hatchers (Cason et al. 1994), amounting to a two- $\log _{10}$ increase in mass of dust in the hatcher compared with the setter incubator in one study (Puterflam et al. 2013). A positive correlation has been observed between the density of airborne micro-organisms in the hatcher and the incidence of chick death associated with infection in the first five days of life (Rudy 1988) and there is a correlation between bacterial species recovered from hatcher air samples and from cases of chick omphalitis (Chute and 
Gershman 1961). It is likely that horizontal spread in the environment is the commonest route by which chicks acquire bacterial pathogens or antimicrobial-resistant bacteria by the time they leave the hatching cabinet (Bailey et al. 1994, 1998, Cason et al. 1994). Further crosscontamination may occur when hatcher cabinets are emptied and newly-hatched birds are handled for sorting and dispatch. Given the immature microbiota of gut and mucosa in poultry at this age, any antimicrobial drugs then administered (typically to counteract omphalitis) can have an intense selective effect, particularly if there has already been some colonisation by AMR bacteria (Saraiva et al. 2018).

Investigations of hatcheries have found hatcher rooms, hatcher cabinets and post-hatch handling facilities often to have Salmonella contamination (Davies et al. 2001, Mueller-Doblies et al. 2013, Martelli et al. 2016). Where Salmonella on incoming eggs is infrequent or absent and upstream cross-contamination is minimal, there may be little or no Salmonella contamination at earlier stages (Davies and Breslin 2004, Kim and Kim 2010, El-Dahshan 2011). Particular challenges to decontamination of hatchers include the preponderance of dust and fluff, which can harbour viable bacteria for extended periods, amounting to years in the case of Salmonella at least (Cox et al. 2000b), plus the necessary ventilation ducting and housing for fan belts that will accumulate such contaminated material and which cannot be cleaned fully without disassembly (Davies and Wray 1994, Christensen et al. 1997, Davies et al. 2001, Mueller-Doblies et al. 2013). Other installations, such as setter incubators with non-removable internal equipment, similarly pose a particular challenge to effective C\&D when compared with models that may readily be stripped down. This difference can be reflected in a higher degree of microbial contamination (Davies and Wray 1994).

A particular issue, evident from several reports, is contamination by Salmonella of hatcher basket (or tray) wash areas (Davies et al. 1997, 2001, Kim and Kim 2010, Mueller-Doblies et al. 2013, Martelli et al. 2016) and washing units (Davies et al. 2003, Davies and Breslin 2004). This focus of contamination can potentially act as a persistent source of the organism for the hatchery environment, and re-introduction of contamination into cleaned hatchers. The efficacy of tray washers for removing Salmonella contamination has been shown to vary substantially (Davies and Wray 1994). Furthermore, in some hatcheries (typically smaller ones) the washers are used for egg trays also, which violates the principle of unidirectional workflow. This creates the further risk of passing hatchery Salmonella strains back to breeder farms.

If Salmonella or other undesirable organisms are present in a hatchery, it is likely that hatchery waste, including meconium, egg and chick remains, will be contaminated. Surveys of Salmonella bear this out (Cox et al. 1997, Davies et al. 2003, Davies and Breslin 2004, Martelli et al. 2016), and such material is considered sensitive and convenient for monitoring purposes (Hy-Line International 2018). Waste that is not handled with due regard for this aspect of its nature may pose a risk for recontamination of the hatchery, including via the ventilation system if it is stored or handled near air intakes (Davies and Wray 1994).

As previously mentioned, there are obstacles to effective C\&D posed by hatcheries, and hatchery environment sampling has demonstrated the potential for extensive contamination of premises by Salmonella (Davies and Wray 1994, Cox et al. 1997, 2001, Davies et al. 2001, Martelli et al. 2016) and the environmental persistence of antibiotic-resistant Enterobacteriaceae (Mueller-Doblies et al. 2013, Dierikx et al. 2013, Osman et al. 2018, Daehre et al. 2018b). Some bacterial strains appear to be adapted for persistence in certain hatchery environments (for example Salmonella Senftenberg), and it is thought that this may in some 
cases relate to biofilm capability (McMullin 2009, Mueller-Doblies et al. 2013, Martelli et al. 2016, Osman et al. 2018).

\section{Evidence for hatchery involvement in pathogen and antimicrobial resistance transmission}

As already outlined, poultry hatcheries are vulnerable to becoming conduits through which micro-organisms pass between generations, multiplying the number of colonised individuals at the hatching stage. Furthermore, mixing of egg batches and persistent environmental contamination may see cross-colonisation of progeny from different source flocks, plus hatcheries acting as reservoirs for pathogens or antimicrobial-resistant organisms. Tracing, sampling and risk-factor studies have documented hatcheries' involvement in these infection and colonisation patterns. Most work on tracing bacteria through hatcheries has concentrated on members of the Enterobacteriaceae, being a group of major significance for both poultry and public health, and also known to show pseudo-vertical transmission.

\section{Hatcheries as conduits and multipliers for microbes: vertical and pseudo-vertical transmission}

There is good evidence that some bacterial pathogens (notably Salmonella Enteritidis, Salmonella Gallinarum biovar Pullorum, and certain Mycoplasma species) can infect ovarian and other reproductive tract tissue, leading to the laying of internally-infected eggs and true vertical transmission between generations (Gast and Holt 2000, Wigley et al. 2001, Berchieri et al. 2001, Armour and Ferguson-Noel 2015). For these pathogens, the limitations of hatcheries for control is understood, and the key tools in their management lie elsewhere, i.e. eliminating or controlling infection in breeding flocks and protecting production flocks from environmental incursion and carryover on the farm premises.

Recent work has tended to concentrate on scenarios where eggs are likely to be initially contaminated externally (i.e. showing pseudo-vertical transmission), and where hatcheries are thought to have a more substantial role in the control, or otherwise, of infection or colonisation of progeny. Studies of Salmonella contamination and colonisation that employ subtyping techniques can provide good evidence of hatcheries acting as conduit and multiplier for such organisms present in breeder flocks. An examination of UK turkey hatcheries found two Salmonella serovars (Derby and Kottbus) to be distributed throughout the production chain from breeder flocks through hatcheries to rearing flocks, with the $S$. Derby isolates showing a consistent antimicrobial resistance pattern (Mueller-Doblies et al. 2013). In a study of UK duck hatcheries, S. Typhimurium DT8 was isolated both in breeder flocks and in the post-hatch area (Martelli et al. 2016). An older study, employing multiple pheno- and genotypic subtyping methods, found closely-related $S$. Enteritidis strains on premises of layer breeder rearing and laying flocks, plus in the corresponding hatchery and the commercial pullet accommodation (Davies et al. 2003).

Two Korean studies have examined integrated broiler companies using pulsed field gel electrophoresis (PFGE) to subtype some Salmonella isolates. Kim et al. (2007) traced $S$. Enteritidis through an integration from parent breeder flock to abattoir via hatchery and production flocks. A study by Ha et al. (2018) showed that PFGE profiles of Salmonella serovars 
Enteritidis, Senftenberg and Montevideo clustered within each of two integrations, and related strains within all these serovars were isolated, variously, from broiler hatchery, flocks and abattoir. Furthermore, in the same study certain other serovars that were not subtyped (Hato, Heidelberg and Hadar) were isolated from breeder levels and one or more of: broiler hatchery, broiler flocks and abattoir.

Evidence of the transmission of non-Salmonella Enterobacteriaceae through hatcheries has also emerged, in a similar pattern to that of Salmonella. A Danish study of four broiler parent flocks supplying a single hatchery identified closely-related subtypes of avian-pathogenic $E$. coli (APEC) in parent birds, newly-hatched chicks and one-week-old chicks suffering mortality (Poulsen et al. 2017). Furthermore, the same study documented substantial horizontal spread of $E$. coli strains between chicks within hatchers over the 24 hour post-hatch period.

In different reports from the same study, evidence of transmission of the Gram-positive potential pathogen Enterococcus faecalis from parent to progeny was also seen from three of the four parent flocks studied, although detail is lacking in the available description (European Commission n.d.). Supporting evidence of vertical or pseudo-vertical transmission of $E$. faecalis is provided by a study of 22 Danish broiler flocks, showing isolation of the organism from $15 \%$ of newly-hatched chicks (Olsen et al. 2012). Furthermore, the authors reported that diseaseassociated subtypes were heavily represented among isolates and the prevalence of colonised chicks increased substantially in the 24 hours post-hatch, indicating horizontal transmission.

Investigation of a Danish broiler integration traced fluoroquinolone (FQ)-resistant E. coli, via PFGE and plasmid typing and in the absence of FQ selection pressure, from parent through eggs and hatchery to production flocks (Petersen et al. 2006). In another study of antimicrobialresistant (AMR) bacteria, observation of the carriage of extended-spectrum cephalosporin (ESC) resistant Enterobacteriaceae from broiler breeders to hatcher debris illustrated the survival of such organisms and the potential for pseudo-vertical transmission that can occur even after eggs are fumigated at the hatchery (Projahn et al. 2016).

\section{Hatcheries as sources of microbes}

Evidence for hatcheries being a source for Salmonella include an epidemiological analysis showing hatchery identity to be a risk factor for Salmonella Typhimurium in broilers (Skov et al. 1999). This was a multivariable analysis showing that breeder flock identity was also, but separately, a risk factor. Sampling and tracing studies provide complementary evidence. A broiler integration in the USA showed frequent Salmonella contamination of hatcher samples, including a persistent serovar (Senftenberg) that was found also in production flocks and carcass rinses but not in the breeder flocks (Bailey et al. 2002). Other studies have also reported a particular tendency for Salmonella Senftenberg to persist in hatcheries (Tenk et al. 2003, McMullin 2009, Mueller-Doblies et al. 2013).

In the UK, poorly-effective C\&D of hatchers was recorded in two hatcheries, with persistent Salmonella contamination by serovars that were also present in progeny flocks (Davies et al. 2001). A Danish study of Salmonella Tennessee in production (but not breeder) broiler flocks identified a link with a hatchery, within which matching $S$. Tennessee strains were found (Christensen et al. 1997). Enhanced C\&D of normally-inaccessible parts of hatchers was associated with resolution of the problem. 
Several studies indicate that, whereas some Salmonella strains may pass through hatcheries only for the time that contaminated eggs are being hatched, others can form resident populations that repeatedly colonise progeny. The two Korean studies of broiler integrations cited earlier in evidence for hatchery transmission between breeder and production flocks also show that hatcheries may be reservoirs for additional Salmonella strains (Kim et al. 2007, Ha et al. 2018). Certain serovars (Enteritidis, Senftenberg, Montevideo and Virchow) were isolated only from hatchery level onwards in the production chain, and PFGE subtyping results of the first three provided additional support for the existence of transmission chains.

Studies on E. coli, and occasionally other non-Salmonella Enterobacteriaceae, also provide evidence of a role for hatcheries as reservoirs or cross-contamination sources for juvenile poultry. A mobile ESC resistance gene (b/a $a_{\mathrm{CMY}-2}$ ) was found on highly similar plasmids in genetically diverse $E$. coli strains from broiler flocks linked to one hatchery in France (Baron et al. 2018), suggesting the hatchery as a site of plasmid transfer between chick-colonising E. coli strains. Five other genetic analyses, reviewed by Dame-Korevaar et al. (2019), demonstrated that E. coli resistance genes to ampicillin or to ESCs in broiler flocks showed clusters of similarity linked to hatcheries of origin.

Projahn et al. (2018) examined E. coli from two antimicrobial-free broiler production chains. Analysis using whole-genome sequences, multi-locus sequence typing (MLST) and singlenucleotide polymorphism analysis indicated that in one chain plasmid-borne ESC resistance $\left(b / a_{\mathrm{cmy}-2}\right)$ was present on clonal isolates detected over several weeks from a flock, plus initially from the truck that transported it to the farm. Similarly- resistant isolates from the parent flock were also related to fattening flock isolates, but not closely enough to infer vertical or pseudovertical transmission. It was concluded they were most likely to have been transferred indirectly from parent to production flocks, via residence in the hatchery.

Two studies have illustrated likely colonisation of hatching flocks by antimicrobial-resistant Enterobacteriaceae derived from unrelated breeder flocks using the same hatchery. In Germany, clonal isolates of multi-drug-resistant Klebsiella pneumoniae, encoding bla $a_{\mathrm{SH}-2}$ extended-spectrum beta-lactamase (ESBL) resistance, were recovered both from a parent flock and the hatchery receiving its eggs, and also from non-related chicks in the same hatchery and throughout the rearing period of the resulting broiler flock (Daehre et al. 2018a). The parent flock of these chicks was not found to be colonised. Similarly, fluoroquinolone-resistant APEC with matching plasmid profiles and PFGE patterns were recovered from Danish breeder flocks plus their progeny flocks and corresponding hatchers (showing vertical or pseudo-vertical transmission), but also from two unrelated production flocks produced later in the same hatchery but without evidence of APEC colonisation of their own breeder flock (Petersen et al. 2006). This study also illustrates likely persistence as well as cross-contamination within a hatchery, and this of an AMR pathogen in the absence of an obvious selective pressure as no $\mathrm{FQ}$ antimicrobials were used in the system.

Persistence of AMR bacteria in hatcheries has also been inferred from environmental sampling studies. Ten Egyptian hatcheries yielded E. coli, with little overlap between serovars isolated from animals (meconium) and from environmental samples. The latter isolates generally showed a stronger biofilm capability in phenotypic tests and different AMR patterns compared with the meconium-derived strains (Osman et al. 2018). It was hypothesised that more vigorous biofilm capability might characterise persistent 'resident' strains. An examination of UK turkey hatcheries yielded FQ-resistant environmental E. coli isolates (that were frequently 
also multi-drug-resistant), predominantly from hatcher interiors and including a sampling visit after C\&D (Mueller-Doblies et al. 2013).

The administration of antimicrobial drugs to eggs or chicks at the hatchery potentially adds a powerful driver to the establishment and spread of hatchery AMR organisms. This is in addition to persistent environmental colonisation, cross-contamination of equipment and eggs, and horizontal transmission between hatchlings. Within the last decade, ESC antimicrobials have been used in several countries to control E. coli-associated mortality around the time of hatching, as well as Enterococcus spp. infection in breeding birds. Amid concerns about responsible use of antimicrobial drugs, and specifically ESBL-type resistances in broiler production, the practice has largely been abandoned, and is no longer legal in certain countries. A review of eight year's avian extra-intestinal clinical E. coli isolates (i.e. APEC-type) in Ontario showed significant temporal correlations between the intensity of specific antimicrobial drug use in hatcheries (the ESC drug ceftiofur, also gentamicin and a lincomycinspectinomycin combination) and the frequencies of resistance to these drugs (Kadykalo et al. 2019).

Looking at faecal E. coli, another Canadian study sampled 371 late-rear broiler flocks for the prevalence of a phenotype typical of the plasmid-borne bla $a_{\mathrm{CM}-2}$, which codes for ceftiofur resistance (Caffrey et al. 2017). Multi-variable modelling revealed that in ovo administration of ceftiofur in the source hatchery correlated with increased prevalence of this phenotype. A Japanese study focussing on faecal E. coli isolates obtained from 362 broiler farms between 2010 and 2013 showed significant and rapid reductions in phenotypic ESC resistance (from over $16 \%$ of isolates in 2010 to $4.6 \%$ in 2013) following cessation of the use of ceftiofur in Japanese hatcheries in 2012 (Hiki et al. 2015).

A four-hatchery French study in 2014 sampled long-lived production flocks (free-range broilers and laying hens) from hatch onwards, some of which had had ceftiofur administered in ovo or at one day of age (Baron et al. 2014). The proportion of ESC-resistant E. coli isolated was significantly greater from treated flocks, compared with unexposed birds, until late in the life of the flocks. Furthermore, for both broiler and layer flocks, the bla CMY-2 $_{\mathrm{CSC}}$-resistant genotype was associated with hatchery of origin but not with ESC treatment, and $86 \%$ of multi-drugresistant isolates were from birds associated with one hatchery.

Thus, antimicrobial treatment at hatcheries may have long-lasting effects on AMR in birds' microbiota, and which may be impacted further by the hatcheries' incoming or resident bacterial populations. An additional factor may be the presence of antimicrobial drugs originating from medicated breeding flocks but persisting within eggs and the resulting chicks and hatcher debris (Jansen et al. 2020).

\section{Studies where hatcheries' roles are uncertain}

In some studies there is evidence of hatchery involvement in bacterial transmission or contamination, but it may be unclear which role (conduit/multiplier or source/reservoir) the hatchery is playing. Dierikx et al. (2013) reported on extended-spectrum cephalosporinaseproducing E. coli, present at all levels from grandparent flocks down and including hatcheries, in a Dutch broiler industry investigation. Detailed subtyping was not performed, leaving open the question about relative contributions of (pseudo)vertical transfer, hatchery reservoir, fomite transfer and carryover on farms. 
Sometimes data from breeders and incoming eggs is missing, so it is unclear from where the problem organisms in progeny originate. In one French study Salmonella serovars isolated from nine hatcheries comprised $15.6 \%$ of isolates from 20 progeny flocks and $5.8 \%$ of associated abattoir isolates (LaHellec and Colin 1985). In another French report there was a clear epidemiological link between a French hatchery and six progeny flocks colonised with multidrug-resistant Salmonella Virchow encoding mobile ESBL genes (Weill et al. 2004). An older study from Canada followed a flock in each of five broiler chains from hatchery to carcass, and in two of these the same Salmonella serovars were isolated at all stages from hatcher onwards (Bhatia and McNabb 1980).

Sampling of chick delivery box liners in Japan revealed transmissible ESBL (bla $a_{\mathrm{CTX}-\mathrm{M}-25}$ ) genes among Enterobacter and Klebsiella isolates (Yossapol et al. 2017). The bacterial species, PFGE profiles and co-resistances showed that ESBL strains coming from each of the three source hatcheries were genetically distinct. Another Japanese study examined E. coli from cases of colibacillosis on four broiler farms, plus meconium and yolk isolates from the hatchery that was used by all farms (Ozaki et al. 2017). Some PFGE sub-types, including an ESBL-encoding strain, were common to the hatchery and colibacillosis cases on farms.

On the other hand, data from some studies may only be available from the incoming (breeder) side plus the hatchery, such as where temporal clusters of Salmonella serovars (Heidelberg, Typhimurium and Hadar) from flock monitoring were linked to the same serovars in fluff samples at the hatchery (Sivaramalingam et al. 2013). Uncertainty may also arise when a strain of a serovar that would not be expected to persistently colonise a hatchery is detected only at hatchery level and below. This is the case in an Australian investigation of a broiler integration including discriminatory sub-typing of Salmonella Typhimurium, where some strains appeared to transmit to production flocks from breeders, some were carried over between production flocks and one strain appeared at the hatchery stage (Crabb et al. 2018). The last of these may represent a strain present but undetected in the parent flock, which underwent dissemination at hatching.

In investigating breeding chain contamination, risk factor analysis is an alternative approach to source identification that can also implicate hatcheries but without necessarily clarifying their role. A Belgian broiler sector study of ceftiofur resistance among E. coli, with sampling of two flocks per farm, revealed the hatchery of origin to be a significant risk factor (Persoons et al. 2011). It was considered likely that the antimicrobial resistances originated in the hatcheries but there was no data from the breeding flocks. In this case, selective pressures were postulated, including undocumented use of cephalosporin antimicrobials at the hatcheries, or co-selection of resistances following use of other antimicrobial drugs. An investigation in Ontario showed certain hatcheries to be protective risk factors for specific antimicrobial resistances in E. coli among chicks at placement (Roberts et al. 2015a). A study from the same group found hatchery identity was in several cases a positive risk factor for antimicrobial resistances in Salmonella isolates from placement and/or pre-slaughter among broiler flocks raised without antimicrobial use (Roberts et al. 2015b). 


\section{Hatchery measures to combat infectious agent transmission}

\section{Hygiene and biosecurity}

Given the foregoing evidence of the importance of microbial ingress and persistence in hatcheries upon the health and bacterial colonisation status of progeny, expert opinion on hatchery management emphasises biosecurity and hygiene measures as being critical to successful operation. Issues and practices that may limit the success of contamination control include: low hatchery capacity for the throughput (influencing work patterns and hygiene routines), inadequate facilities or methods for decontaminating egg trays and other fomites, and difficult access for C\&D in and around equipment. There are also problems with the application of some disinfectants at the correct concentration for control of bacteria, relating to corrosion or staff safety and comfort (Davies and Wray 1994, Tenk et al. 1995, Davies and Breslin 2004, Thermote 2006, McMullin 2009, Somolinos 2015).

Recommendations for optimal hatchery biosecurity and hygiene have been made by various authors (Davies and Wray 1994, Samberg and Meroz 1995, Thermote 2006, McMullin 2009, Hubbard 2015, Anon. 2016, Bennett 2017, Dorko 2019). In many cases these are focussed on Salmonella control, but the environmental resilience of Salmonella and its modes of transfer in eggs and elsewhere mean that measures adopted will likely be similarly effective against other infectious agents or commensal intestinal bacteria that share similar modes of transmission. It is notable that a focus on biosecurity and hygiene has been associated with considerable success in controlling Salmonella contamination in hatchery waste and chicks (Cox et al. 1997, Heyndrickx et al. 2002, van der Fels-Klerx et al. 2008).

Hatchery premises should be fenced and are best located away from centres of poultry population, other livestock farms, major roads and feed mills. Hatchery layout should allow work patterns that avoid moving equipment or personnel from dirtier areas through cleaner ones. Capacity should permit single-batch use of separate rooms of setter incubators and hatchers, with thorough C\&D between each batch. Ventilation and insulation should avoid condensation, use pressure gradients to keep air flowing from cleaner to dirtier areas and use methods (for example filters, ultraviolet [UV] light and careful placement of ducting) to ensure clean incoming air and avoid recirculation (Davies and Wray 1994). The water supply should also be clean and subject to sanitary treatment. Measures to prevent incursion to the premises by pests and wildlife are also relevant.

Staff should avoid contact with other livestock, but they and mobile equipment should still be managed as if contaminated. This requires measures such as regular cleaning/showering and hand sanitising, footbaths, vehicle wheel-baths, dedicated clothing, disposable coveralls and foot covers for visiting staff (typically drivers), and labelling of egg trays to dedicate them to a single supply farm. Staff also should not work whilst ill, especially after foreign travel.

Eggs should be fumigated or otherwise disinfected on arrival. In fact, sanitising eggs as close to the point of lay as possible, when invading bacteria are most likely to be susceptible to surface treatments, implies that similar treatments ought to be performed on the farm of origin or in transit as well (Cox et al. 2000b). However, when this is done, the benefits appear to be quite dependent on the exact technique(s) used (Davies and Wray 1994, Mueller-Doblies et al. 2013). Consequently, the importance of egg hygiene on the breeding farm, particularly the provision and cleanliness of nest boxes and rejection of floor-laid eggs, should not be neglected (Berrang et al. 1997). 
The restriction or abandonment of formaldehyde as a fumigant in some countries because of human hazard concerns has promoted the evaluation and use of alternatives that include surface-applied aqueous disinfectants, such as chlorine-based agents, quaternary ammonium compounds and hydrogen peroxide $\left(\mathrm{H}_{2} \mathrm{O}_{2}\right)$, and/or irradiation with UV light. The first two, when applied sequentially via pressure sprays, provided effective decontamination but appeared to make eggs more susceptible to microbial regrowth later in incubation when compared with clean, untreated eggs (Berrang et al. 1997). Simultaneous UV and $\mathrm{H}_{2} \mathrm{O}_{2}$ treatments have been shown to work synergistically (Gottselig et al. 2016, Rehkopf et al. 2017).

Some attempts have also been made to evaluate treatment effects on bacteria that have penetrated the shell. Studies have indicated that neither formaldehyde nor UV light penetrate effectively beyond the shell surface (Williams and Siegel 1969, De Reu et al. 2006), but a simultaneous combination of surfactant and vacuum treatments substantially improved the efficacy of $\mathrm{H}_{2} \mathrm{O}_{2}$ against experimental deep penetration of shells by Salmonella Typhimurium (Cox et al. 2000a). However, this required methods unsuited to a commercial high-throughput environment.

Fumigation or antimicrobial fogging treatments can also be applied in cabinets during hatching to reduce bacterial challenge (Davies and Wray 1994, Bailey et al. 1996, Mitchell et al. 2002). Formaldehyde has been used for many years in hatchers by evaporation of formalin and is helpful for reducing airborne micro-organisms, including Salmonella (Sheldon and Brake 1991, Kim and Kim 2010), but its use does not prevent resident contamination of hatchers by bacterial biofilms. Work has been performed on alternatives to formaldehyde used in this mode, which include chemical agents (ozone, fogging with $\mathrm{H}_{2} \mathrm{O}_{2}$ ) or physical treatments (UV irradiation or ionisation of air to remove suspended matter). Some of these have shown reductions in airborne contamination by Enterobacteriaceae as well as the incidence or degree of Salmonella colonisation of young chicks (Bailey et al. 1996, Mitchell et al. 2002).

In addition to sanitary treatments focussed on eggs and hatching, there needs to be regular $C \& D$ of premises, equipment and of moveable fomites including setter trays, hatcher baskets, chick delivery boxes and egg buggies from farms (Thermote 2006, McMullin 2009). The tray wash machines can themselves become persistently contaminated by bacterial biofilm if operated at low temperatures with disinfectants that are unsuitable or used at inadequate concentrations. Multi-stage setter incubators should be avoided, as they do not operate on an all-in-all-out basis and so cannot be regularly and thoroughly cleaned and disinfected (Davies and Wray 1994, Dorko 2019). Indeed, workflow and capacity issues that prevent thorough C\&D of other equipment, including strip-down procedures and access to ventilation systems, can present a similar problem elsewhere. There is a need to design hatchery equipment to be heatresistant, so that resident bacteria can be eliminated by steam heat or combined heat and chemical biocide action, since no biocide treatment can be fully effective within equipment that is difficult to clean and subject to biofilm formation (Yuan et al. 2019).

Other identified challenges include: egg transfer equipment (which appears to be readily recontaminated), access around and within non-movable equipment, management of areas handling egg and chick waste (such as macerators/separators, holding vessels or skips), and leakage from waste pipes (Davies and Wray 1994, Davies et al. 2001). Furthermore, consideration needs to be given to the positioning of waste skips and dust extraction vents from chick processing and wash/waste areas, which are often located close to lorry wash facilities. Such proximity could be responsible for contamination of egg and chick delivery 
vehicles and the footwear of drivers, which consequently present a risk of transfer of microorganisms back to breeding farms or on to farms receiving chicks.

Despite the evident challenges to effective $C \& D$ in hatcheries, intensive sampling studies have shown that concerted action can lead to the substantial reduction or indeed elimination of Salmonella contamination (Davies and Wray 1994, Martelli et al. 2016). To assess the adequacy of C\&D and hygienic operation, environmental monitoring may include swabs for total viable counts, coliforms and fungi, plus air sampling by technical samplers or settle plates (McMullin 2009).

Studies of higher-level breeder hatcheries show better Salmonella control than for production flock hatcheries (Cox et al. 1991, Ha et al. 2018). Whilst this may reflect better management and resources for hatching of high-value eggs, it also points to likely better microbiological quality of the incoming eggs from high-level breeding flocks, illustrating that biosecurity extends beyond the hatchery. Many hygiene and biosecurity issues for hatcheries apply also to breeding flocks, for example: location, layout, operating patterns and practices including $C \& D$, pest control, wildlife exclusion, water sanitation and microbiological monitoring (Dorko 2019). However, other breeding flock considerations, such as feed supply, vaccination policies, and discarding floor-laid eggs (Mah 2019) will differ from hatchery-based concerns.

\section{Other measures}

Within hatcheries, the principal measures other than biosecurity and hygiene to manage risk of Salmonella infection in chicks are: sensitive monitoring for such contamination, plus an action plan in the event of identified issues. Good sites and materials for routine Salmonella monitoring samples after each hatch include: hatcher baskets and associated waste (including dead embryos), hatcher surfaces, chick transfer belts and chick box liners (McMullin 2009, Hubbard 2015, Hy-Line International 2018, Dorko 2019). Regular but less frequent sampling of surfaces in the incubator and hatching rooms is recommended, to assess adequacy of C\&D, plus monitoring of water supply and any trapped pest species (Hubbard 2015).

Conventional enrichment plus selective culture and phenotypic typing techniques remain key to isolating, identifying and characterising Salmonella, but initial screening of samples by polymerase chain reaction can complement this by providing rapid and sensitive detection (Hubbard 2015, Hy-Line International 2018). Whole genome sequencing has become the method of choice for accurate strain discrimination. In the event of Salmonella isolation, the action plan should both address existing contamination and investigate likely sources. Previous investigations indicate that a strip-down of equipment (particularly hatchers and ventilation ducts) may be needed to identify otherwise hidden sources of ongoing contamination (Davies and Wray 1994, Christensen et al. 1997). Similar sampling, of hatchery waste, hatchers and further upstream can be conducted if there is a suspected problem with AMR bacteria emerging from the hatchery, using phenotypic and/or genotypic screening of isolates. Typically, such sampling for resistant bacteria is confined to research investigations at present (Dierikx et al. 2013, Osman et al. 2018). Metagenomic approaches may be useful to characterise the 'resistome' of hatcheries and their output of chicks and waste in more detail. 
Hatcheries are very limited in the controls they can exert over truly vertically-transmitted infections. Apart from not accepting eggs from infected breeder flocks, the hatchery has three principal tools in this regard. These are: the stringent separation of eggs of different origins at the time of hatch, to avoid horizontal transmission (McMullin 2009), excellent hygiene in hatchers and the post-hatch environment, and the exclusion of wild birds. The last two, which should be integral to hatcheries' hygiene and biosecurity regime, avoids chicks being exposed to organisms that are persistent in their environment or that are introduced by external agents (Bradbury 2006, Vereecken et al. 2009).

\section{Discussion}

Hatcheries are an integral part of poultry production chains and, owing to the biology of avian reproduction, they represent an opportunity for microbiological segregation between generations that can be very helpful for infectious disease control. Nonetheless, there are welldocumented challenges for hatcheries to prevent the ingress of infectious agents and their subsequent spread and transmission. Furthermore, hatcheries by their nature are a focus, both for incoming eggs (potentially from many breeder flocks) and for the output of progeny flocks. In consequence, far from being a firebreak for infectious agents, hatcheries potentially can act as enablers of the multiplication and dissemination of infections between poultry generations.

The risks of Salmonella and APEC transmission through hatcheries have been recognised for many years, but there has been a more recent appreciation also of problems associated with AMR, with evidence of this accumulating principally in respect of Enterobacteriaceae. This has followed wider concerns about the emergence of ESBL-type mobile resistance in the broiler industry and disquiet about strategies to control omphalitis and other hatchery-associated infections by using antimicrobial drugs around the time of hatch.

Individual studies have confirmed hatchery contributions to the colonisation of poultry flocks by various members of the Enterobacteriaceae, but it is clear there are other sources of bacterial pathogens and AMR organisms within the production pathways, and the relative contribution of hatcheries in the bigger picture remains largely unquantified. The use of highly discriminating subtyping methods, including next generation sequencing, may contribute to further clarification of the situation, provided that sampling studies looking at flocks from several generations within an integration, plus hatcheries, are performed. In this way, the principal roles played by hatcheries, breeding flocks and environment, and their relative importance, can be better established. This should allow resources to control the transfer and multiplication of pathogens and AMR to be deployed to best effect. Some such multi-level studies have been performed, but evidence to date is fragmentary.

Hygiene and biosecurity are key to hatcheries exerting a positive, controlling role upon infectious agents in the poultry production chain. Given the many contributing flocks to a hatchery's intake of eggs, with their accompanying microbiological burden, it is important that the notion of hatchery biosecurity extends to conditions and practices on the breeder premises and during transportation of eggs and chicks. Although there are many challenges to excellent hygiene within a hatchery, modern successes with Salmonella control in many cases illustrate what can be achieved. 


\section{Funding details}

The review was funded by the UK Department for Environment, Food and Rural Affairs (Defra), project FZ2000

\section{Disclosure statement}

The authors disclose no conflicts of interest.

\section{References}

ANON. 2016, July 3. Prevention of cross-contamination in the hatchery. Hatchery Practice (Zootecnica International). https://zootecnicainternational.com/poultry-facts/steps-for-the-prevention-of-crosscontamination-in-the-hatchery (accessed 30 September 2019).

ARMOUR, N. K. and FERGUSON-NOEL, N. 2015. Evaluation of the egg transmission and pathogenicity of Mycoplasma gallisepticum isolates genotyped as ts-11. Avian Pathology 44: 296-304.

BAILEY, J. S., BUHR, R. J., COX, N. A. and BERRANG, M. E. 1996. Effect of hatching cabinet sanitation treatments on Salmonella cross-contamination and hatchability of broiler eggs. Poultry Science 75: 191-196.

BAILEY, J. S., CASON, J. A. and COX, N. A. 1998. Effect of Salmonella in young chicks on competitive exclusion treatment. Poultry Science 77: 394-399.

BAILEY, J. S., COX, N. A. and BERRANG, M. E. 1994. Hatchery-acquired salmonellae in broiler chicks. Poultry Science 73: 1153-1157.

BAILEY, J. S., COX, N. A., CRAVEN, S. E. and COSBY, D. E. 2002. Serotype tracking of Salmonella through integrated broiler chicken operations. Journal of Food Protection 65: 742-745.

BARON, S., JOUY, E., LARVOR, E., EONO, F., BOUGEARD, S. and KEMPF, I. 2014. Impact of thirdgeneration-cephalosporin administration in hatcheries on fecal Escherichia coli antimicrobial resistance in broilers and layers. Antimicrobial Agents and Chemotherapy 58: 5428-5434.

BARON, S., LE DEVENDEC, L., TOUZAIN, F., JOUY, E., LUCAS, P., DE BOISSÉSON, C., LARVOR, E. and KEMPF, I. 2018. Longitudinal study of Escherichia coli plasmid resistance to extended-spectrum cephalosporins in free-range broilers. Veterinary Microbiology 216: 20-24.

BENNETT, B. 2017. The importance of biosecurity in the modern day hatchery. International Hatchery Practice 31: 21-23.

BERCHIERI, A., MURPHY, C. K., MARSTON, K. and BARROW, P. A. 2001. Observations on the persistence and vertical transmission of Salmonella enterica serovars Pullorum and Gallinarum in chickens: effect of bacterial and host genetic background. Avian Pathology 30: 221-231.

BERRANG, M. E., COX, N. A., FRANK, J. F. and BUHR, R. J. 1999. Bacterial penetration of the eggshell and shell membranes of the chicken hatching egg: A review. Journal of Applied Poultry Research 8: $499-504$.

BERRANG, M. E., FRANK, J. F., BUHR, R. J., BAILEY, J. S., COX, N. A. and MAULDIN, J. M. 1997. Microbiology of sanitized broiler hatching eggs through the egg production period. Journal of Applied Poultry Research 6: 298-305.

BHATIA, T. R. S. and MCNABB, G. D. 1980. Dissemination of Salmonella in broiler-chicken operations. Avian Diseases 24: 616-624.

BRADBURY, J. M. 2006. Mycoplasmas - ever present pathogens? International Hatchery Practice 20: 21-23. BYRD, J. A., CORRIER, D. E., DELOACH, J. R., NISBET, D. J. and STANKER, L. H. 1998. Horizontal transmission of Salmonella typhimurium in broiler chicks. Journal of Applied Poultry Research 7: 75-80.

CAFFREY, N., NEKOUEI, O., GOW, S., AGUNOS, A. and CHECKLEY, S. 2017. Risk factors associated with the A2C resistance pattern among $E$. coli isolates from broiler flocks in Canada. Preventive Veterinary Medicine 148: 115-120.

CASON, J. A., COX, N. A. and BAILEY, J. S. 1994. Transmission of Salmonella typhimurium during hatching of broiler chicks. Avian Diseases 38: 583-588.

CHRISTENSEN, J. P., BROWN, D. J., MADSEN, M., OLSEN, J. E. and BISGAARD, M. 1997. Hatcheryborne Salmonella enterica serovar Tennessee infections in broilers. Avian Pathology 26: 155-168. 
CHUTE, H. L. and GERSHMAN, M. 1961. A new approach to hatchery sanitation. Poultry Science 40: 568571.

COX, N. A., BAILEY, J. S. and BERRANG, M. E. 1996. Alternative routes for Salmonella intestinal tract colonization of chicks. The Journal of Applied Poultry Research 5: 282-288.

COX, N. A., BAILEY, J. S., BERRANG, M. E. and MAULDIN, J. M. 1997. Diminishing incidence and level of Salmonellae in commercial broiler hatcheries. Journal of Applied Poultry Research 6: 90-93.

COX, N. A., BAILEY, J. S., MAULDIN, J. M., BLANKENSHIP, L. C. and WILSON, J. L. 1991. Extent of salmonellae contamination in breeder hatcheries. Poultry Science 70: 416-418.

COX, N. A., BERRANG, M. E., BUHR, R. J. and BAILEY, J. S. 2000a. Bactericidal treatment of hatching eggs IV. Hydrogen peroxide applied with vacuum and a surfactant to eliminate Salmonella from hatching eggs. Journal of Applied Poultry Research 9: 530-534.

COX, N. A., BERRANG, M. E. and CASON, J. A. 2000b. Salmonella penetration of egg shells and proliferation in broiler hatching eggs - a review. Poultry Science 79: 1571-1574.

COX, N. A., BERRANG, M. E. and MAULDIN, J. M. 2001. Extent of salmonellae contamination in primary breeder hatcheries in 1998 as compared to 1991. Journal of Applied Poultry Research 10: 202-205.

CRABB, H. K., ALLEN, J. L., DEVLIN, J. M., FIRESTONE, S. M., WILKS, C. R. and GILKERSON, J. R. 2018. Salmonella spp. transmission in a vertically integrated poultry operation: clustering and diversity analysis using phenotyping (serotyping, phage typing) and genotyping (MLVA). PLOS ONE 13: e201031.

DAEHRE, K., PROJAHN, M., FRIESE, A., SEMMLER, T., GUENTHER, S. and ROESLER, U. H. 2018a. ESBL-producing Klebsiella pneumoniae in the broiler production chain and the first description of ST3128. Frontiers in Microbiology 9: Article 2302. DOI: 10.3389/fmicb.2018.02302

DAEHRE, K., PROJAHN, M., SEMMLER, T., ROESLER, U. and FRIESE, A. 2018b. Extended-spectrum beta-lactamase-/AmpC beta-lactamase-producing Enterobacteriaceae in broiler farms: transmission dynamics at farm level. Microbial Drug Resistance 24: 511-518.

DAME-KOREVAAR, A., FISCHER, E. A. J., VAN DER GOOT, J., STEGEMAN, A. and MEVIUS, D. 2019. Transmission routes of ESBL/pAmpC producing bacteria in the broiler production pyramid, a literature review. Preventive Veterinary Medicine 162: 136-150.

DAVIES, R., BRESLIN, M., CORRY, J. E., HUDSON, W. and ALLEN, V. M. 2001. Observations on the distribution and control of Salmonella species in two integrated broiler companies. Veterinary Record 149: 227232.

DAVIES, R. H. and BRESLIN, M. F. 2004. Observations on the distribution and control of Salmonella contamination in poultry hatcheries. British Poultry Science 45 Suppl. 1: S12-14.

DAVIES, R. H., NICHOLAS, R. A. J., MCLAREN, I. M., CORKISH, J. D., LANNING, D. G. and WRAY, C. 1997. Bacteriological and serological investigation of persistent Salmonella enteritidis infection in an integrated poultry organisation. Veterinary Microbiology 58: 277-293.

DAVIES, R. H. and WRAY, C. 1994. An approach to reduction of Salmonella infection in broiler chicken flocks through intensive sampling and identification of cross-contamination hazards in commercial hatcheries. International Journal of Food Microbiology 24: 147-160.

DAVIES, R., LIEBANA, E. and BRESLIN, M. 2003. Investigation of the distribution and control of Salmonella enterica serovar Enteritidis PT6 in layer breeding and egg production. Avian Pathology 32: 227-37.

DE REU, K., GRIJSPEERDT, K., HERMAN, L., HEYNDRICKX, M., UYTTENDAELE, M., DEBEVERE, J., PUTIRULAN, F. F. and BOLDER, N. M. 2006. The effect of a commercial UV disinfection system on the bacterial load of shell eggs. Letters in Applied Microbiology 42: 144-148.

DE REU, K., MESSENS, W., HEYNDRICKX, M., RODENBURG, T. B., UYTTENDAELE, M. and HERMAN, L. 2008. Bacterial contamination of table eggs and the influence of housing systems. World's Poultry Science Journal 64: 5-19.

DIERIKX, C. M., VAN DER GOOT, J. A., SMITH, H. E., KANT, A. and MEVIUS, D. J. 2013. Presence of ESBL/AmpC -producing Escherichia coli in the broiler production pyramid: a descriptive study. PLOS ONE 8: e79005. DOI: 10.1371/journal.pone.0079005

DORKO, N. 2019. Salmonella: how do we maintain freedom in our poultry flocks? International Hatchery Practice 33: 9-10.

EL-DAHSHAN, A. R. 2011. Microbiological examinations and hygienic evaluation of duck hatcheries in Egypt. In: Proceedings of the 4th Scientific Conference of Animal Wealth Research in the Middle East and North Africa, 3-5 October. Foreign Agricultural Relations (FAR), Egypt, p. 248-259. https://www.cabdirect.org/cabdirect/abstract/20113392513 (accessed 27 January 2020). 
EUROPEAN COMMISSION. (n.d.). Final Report Summary - PROHEALTH (Sustainable intensive pig and poultry production) https://cordis.europa.eu/project/rcn/110835/reporting/en (accessed 16 September 2019).

VAN DER FELS-KLERX, H. J., JACOBS-REITSMA, W. F., VAN BRAKEL, R., VAN DER VOET, H. and VAN ASSELT, E. D. 2008. Prevalence of Salmonella in the broiler supply chain in The Netherlands. Journal of Food Protection 71: 1974-1980.

GAST, R. K. and HOLT, P. S. 2000. Deposition of phage type 4 and 13a Salmonella enteritidis strains in the yolk and albumen of eggs laid by experimentally infected hens. Avian Diseases 44: 706-710.

GOTTSElig, S. M., DUNN-HORROCKS, S. L., WOODRING, K. S., COUFAL, C. D. and DUONG, T. 2016. Advanced oxidation process sanitization of eggshell surfaces. Poultry Science 95: 1356-1362.

HA, J. S., SEO, K. W., KIM, Y. B., KANG, M. S., SONG, C.-S. and LEE, Y. J. 2018. Prevalence and characterization of Salmonella in two integrated broiler operations in Korea. Irish Veterinary Journal 71: Article 3. DOI: $10.1186 / \mathrm{s} 13620-018-0114-4$

HEYNDRICKX, M., VANDEKERCHOVE, D., HERMAN, L., ROLLIER, I., GRIJSPEERDT, K. and DE ZUTTER, L. 2002. Routes for salmonella contamination of poultry meat: epidemiological study from hatchery to slaughterhouse. Epidemiology and Infection 129: 253-265.

HIKI, M., KAWANISHI, M., ABO, H., KOJIMA, A., KOIKE, R., HAMAMOTO, S. and ASAI, T. 2015. Decreased resistance to broad-spectrum cephalosporin in Escherichia coli from healthy broilers at farms in Japan after voluntary withdrawal of ceftiofur. Foodborne Pathogens and Disease 12: 639-643.

HUBBARD, O. L. 2015. Taking steps towards a salmonella free hatchery. International Hatchery Practice 29 : $12-13$.

HY-LINE INTERNATIONAL. 2018. Monitoring breeder flocks for salmonella, mycoplasma and avian influenza. International Hatchery Practice 32: 11-13.

JANSEN, L. J. M., BERENTSEN, R. J., ARENDS, M. and BERENDSEN, B. J. A. 2020. The vertical transmission of antibiotic residues from parent hens to broilers. Food Additives \& Contaminants: Part A Early view online: 10 pp. DOI: 10.1080/19440049.2020.1725147

KADYKALO, S. V., PEARL, D. L., SLAVIC, D. and MCEWEN, S. A. 2019. Resistance to antimicrobials used at hatchery level among clinical Escherichia coli isolates from Ontario broilers. The Canadian Veterinary Journal - La Revue Veterinaire Canadienne 60: 945-954.

KIM, A., YOUNG, J. L., MIN, S. K., SANG, I. K. and JAE, K. C. 2007. Dissemination and tracking of Salmonella spp. in integrated broiler operation. Journal of Veterinary Science 8: 155-161.

KIM, J. H. and KIM, K. S. 2010. Hatchery hygiene evaluation by microbiological examination of hatchery samples. Poultry Science 89: 1389-1398.

KUBASOVA, T., KOLlARCIKOVA, M., CRHANOVA, M., KARASOVA, D., CEJKOVA, D., SEBKOVA, A., MATIASOVICOVA, J., FALDYNOVA, M., POKORNA, A., CIZEK, A. and RYCHLIK, I. 2019. Contact with adult hen affects development of caecal microbiota in newly hatched chicks. PLOS ONE 14: e0212446. DOI: 10.1371/journal.pone.0212446

LAHELLEC, C. and COLIN, P. 1985. Relationship between serotypes of salmonellae from hatcheries and rearing farms and those from processed poultry carcases. British Poultry Science 26: 179-186.

МАH, C. K. 2019. E. coli - the underestimated broiler breeder pathogen. International Hatchery Practice 33: 11-13.

MARTELLI, F., BIRCH, C. and DAVIES, R. H. 2016. Observations on the distribution and control of Salmonella in commercial duck hatcheries in the UK. Avian Pathology 45: 261-266.

MCMULLIN, P. F. 2009. Hygiene and microbiological control in hatcheries. Avian Biology Research 2: 9397.

MILNER, K. C. and SHAFFER, M. F. 1952. Bacteriologic studies of experimental Salmonella infections in chicks. The Journal of Infectious Diseases 90: 81-96.

MITCHELL, B. W., BUHR, R. J., BERRANG, M. E., BAILEY, J. S. and COX, N. A. 2002. Reducing airborne pathogens, dust and Salmonella transmission in experimental hatching cabinets using an electrostatic space charge system. Poultry Science 81: 49-55.

MORROW, C. J. and BROWNING, G. F. 2018. The role of control of avian mycoplasmas in antimicrobial stewardship. International Hatchery Practice 32: 11-13.

MUELlER-DOBLIES, D., CLOUTING, C. and DAVIES, R. H. 2013. Investigations of the distribution and persistence of Salmonella and ciprofloxacin-resistant Escherichia coli in turkey hatcheries in the UK. Zoonoses and Public Health 60: 296-303. 
OLSEN, R. H., CHRISTENSEN, H. and BISGAARD, M. 2012. Transmission and genetic diversity of Enterococcus faecalis during hatch of broiler chicks. Veterinary Microbiology 160: 214-221.

OSMAN, K. M., KAPPELL, A. D., ELHADIDY, M., ELMOUGY, F., EL-GHANY, W. A. A., ORABI, A., MUBARAK, A. S., DAWOUD, T. M., HEMEG, H. A., MOUSSA, I. M. I., HESSAIN, A. M. and YOUSEF, H. M. Y. 2018. Poultry hatcheries as potential reservoirs for antimicrobial-resistant Escherichia coli : A risk to public health and food safety. Scientific Reports 8: Article 5859. DOI: 10.1038/s41598-018-23962-7

OZAKI, H., MATSUOKA, Y., NAKAGAWA, E. and MURASE, T. 2017. Characteristics of Escherichia coli isolated from broiler chickens with colibacillosis in commercial farms from a common hatchery. Poultry Science 96: 3717-3724.

PERSOONS, D., HAESEBROUCK, F., SMET, A., HERMAN, L., HEYNDRICKX, M., MARTEL, A., CATRY, B., BERGE, A. C., BUTAYE, P. and DEWULF, J. 2011. Risk factors for ceftiofur resistance in Escherichia coli from Belgian broilers. Epidemiology and Infection 139: 765-771.

PETERSEN, A., CHRISTENSEN, J. P., KUHNERT, P., BISGAARD, M. and OLSEN, J. E. 2006. Vertical transmission of a fluoroquinolone-resistant Escherichia coli within an integrated broiler operation. Veterinary Microbiology 116: 120-128.

POLLOCK, D. L. 1999. A geneticist's perspective from within a broiler primary breeder company. Poultry Science 78: 414-418.

POULSEN, L. L., THØFNER, I., BISGAARD, M., CHRISTENSEN, J. P., OLSEN, R. H. and CHRISTENSEN, H. 2017. Longitudinal study of transmission of Escherichia coli from broiler breeders to broilers. Veterinary Microbiology 207: 13-18.

PROJAHN, M., DAEHRE, K., ROESLER, U. and FRIESE, A. 2016. Extended-spectrum-beta-lactamaseand plasmid-encoded cephamycinase-producing enterobacteria in the broiler hatchery as a potential mode of pseudo-vertical transmission. Applied and Environmental Microbiology 83: e02364. DOI: 10.1128/AEM.0236416

PROJAHN, M., DAEHRE, K., SEMMLER, T., GUENTHER, S., ROESLER, U. and FRIESE, A. 2018. Environmental adaptation and vertical dissemination of ESBL-/pAmpC-producing Escherichia coli in an integrated broiler production chain in the absence of an antibiotic treatment. Microbial Biotechnology 11: 10171026.

PUTERflaM, J., AUDREN, C., BOUQUIN, S. le, WAVELET, E. and DEWITTE, J. D. 2013.

AIRCOUV: impact sanitaire de l'empoussierement dans les couvoirs [health impact of dust in hatcheries]. In: Actes des 10èmes Journées de la Recherche Avicole et Palmipèdes à Foie Gras du 26 au 28 mars. La Rochelle, France, p. 160-164. https://www.cabdirect.org/cabdirect/abstract/20133303088 (accessed 3 February 2020).

REHKOPF, A. C., BYRD, J. A., COUFAL, C. D. and DUONG, T. 2017. Advanced Oxidation Process sanitization of hatching eggs reduces Salmonella in broiler chicks. Poultry Science 96: 3709-3716.

ROBERTS, T., MCEWEN, S., REID-SMITH, R., SARGEANT, J., AGUNOS, A., LÉGER, D. and GUERIN, M. 2015a. Risk factors for antimicrobial resistance of Escherichia coli isolates from Ontario broiler chicken flocks at chick placement: a comparison of three production system types. In: Proceedings of 64th Western Poultry Disease Conference, March 22-25. Sacramento, California, USA.

ROBERTS, T., MCEWEN, S., REID-SMITH, R., SARGEANT, J., AGUNOS, A., LÉGER, D. and GUERIN, M. 2015b. Prevalence, risk factors, and profiles of resistant Salmonella isolates obtained from Ontario broiler chicken farms at chick placement and pre-harvest. In: Proceedings of 64th Western Poultry Disease Conference, March 22-25. Sacramento, California, USA.

RUDY, A. 1988. Wpływ zakażenia drobnoustrojami aparałów klujnikowych na stan zdrowotny brojlerów kurzych w pierwszych dniach życia [Effects of the microbial contamination of hatching apparatuses on the state of health of broiler chicks during their first few days of life]. Medycyna Weterynaryjna 44: 218-220.

SAMBERG, Y. and MEROZ, M. 1995. Application of disinfectants in poultry hatcheries. Revue scientifique et technique (International Office of Epizootics) 14: 365-380.

SARAIVA, M. M. S., MOREIRA FILHO, A. L. B., FREITAS NETO, O. C., SILVA, N. M., GIVISIEZ, P. E. N., GEBREYES, W. A. and OLIVEIRA, C. J. B. 2018. Off-label use of ceftiofur in one-day chicks triggers a short-term increase of ESBL- producing E. coli in the gut. PLOS ONE 13: e0203158. DOI: 10.1128/AEM.02364-16

SHELDON, B. W. and BRAKE, J. 1991. Hydrogen peroxide as an alternative hatching egg disinfectant. Poultry Science 70: 1092-1098. 
SILVETTI, T., MORANDI, S., HINTERSTEINER, M. and BRASCA, M. 2017. Use of hen egg white lysozyme in the food industry, in P. Y. HESTER (Ed.) Egg Innovations and Strategies for Improvements, pp. 233-242 (San Diego, Academic Press).

SIVARAMAlingaM, T., MCEWEN, S. A., PEARL, D. L., OJKIC, D. and GUERIN, M. T. 2013. A temporal study of Salmonella serovars from environmental samples from poultry breeder flocks in Ontario between 1998 and 2008. Canadian Journal of Veterinary Research - Revue Canadienne de Recherche Veterinaire 77: 1-11.

SKOV, M. N., ANGEN, O., CHRIEL, M., OLSEN, J. E. and BISGAARD, M. 1999. Risk factors associated with Salmonella enterica serovar typhimurium infection in Danish broiler flocks. Poultry Science 78: 848-854.

SOMOLINOS, M. 2015. Intelligent disinfection of breeder farms: the key point of profitability. International Hatchery Practice 29: 13-15.

TENK, I., KOSTYAK, A. and MATRAY, D. 1995. Hygienic conditions of hatcheries with special reference to the incidence of salmonellae. Magyar Allatorvosok Lapja 50: 331-334.

TENK, I., KOSTYAK, A. and MATRAY, D. 2003. Data on the survival of salmonellas in hatcheries for water-fowls. Magyar Allatorvosok Lapja 125: 595-599.

THERMOTE, L. 2006. Effective hygiene within the hatchery. International Hatchery Practice 20: 18-21.

VARMUZOVA, K., KUBASOVA, T., DAVIDOVA-GERZOVA, L., SISAK, F., HAVLICKOVA, H., SEBKOVA, A., FALDYNOVA, M. and RYCHLIK, I. 2016. Composition of gut microbiota influences resistance of newly hatched chickens to Salmonella Enteritidis infection. Frontiers in Microbiology 7: Article 957. DOI: 10.1128/AEM.02364-16

VEREECKEN, M., KANORA, A. and DE GUSSEM, K. 2009. Mycoplasma infections in poultry breeders. International Hatchery Practice 23: 17.

VIDENSKA, P., SEDLAR, K., LUKAC, M., FALDYNOVA, M., GERZOVA, L., CEJKOVA, D., SISAK, F. and RYCHLIK, I. 2014. Succession and replacement of bacterial populations in the caecum of egg laying hens over their whole life. PLOS ONE 9: e115142. DOI: 10.1371/journal.pone.0115142

WEILL, F.-X., LAILLER, R., PRAUD, K., KÉROUANTON, A., FABRE, L., BRISABOIS, A., GRIMONT, P. A. D. and CLOECKAERT, A. 2004. Emergence of extended-spectrum- $\beta$-lactamase (CTX-M9)-producing multiresistant strains of Salmonella enterica serotype Virchow in poultry and humans in France. Journal of Clinical Microbiology 42: 5767-5773.

WIGLEY, P., BERCHIERI, A., PAGE, K. L., SMITH, A. L. and BARROW, P. A. 2001. Salmonella enterica serovar Pullorum persists in splenic macrophages and in the reproductive tract during persistent, disease-free carriage in chickens. Infection and Immunity 69: 7873-7879.

WILLIAMS, J. E. and SIEGEL, H. S. 1969. Formaldehyde levels on and in chicken eggs following preincubation fumigation. Poultry Science 48: 552-558.

YASSIN, H., VELTHUIS, A. G. J., BOERJAN, M., VAN RIEL, J. and HUIRNE, R. B. M. 2008. Field study on broiler eggs hatchability. Poultry Science 87: 2408-2417.

YOSSAPOL, M., SUGIYAMA, M. and ASAI, T. 2017. The occurrence of CTX-M-25-producing Enterobacteriaceae in day-old broiler chicks in Japan. Journal of Veterinary Medical Science 79: 1644-1647.

YUAN, L., HANSEN, M. F., RøDER, H. L., WANG, N., BURMØLLE, M. and HE, G. 2019. Mixedspecies biofilms in the food industry: current knowledge and novel control strategies. Critical Reviews in Food Science and Nutrition Early view online: 17 pp. DOI: 10.1080/10408398.2019.1632790 